\title{
Land use change in the Atlantic Forest affects carbon and nitrogen sources of streams as revealed by the isotopic composition of terrestrial invertebrates
}

\author{
Fernanda Gaudio Augusto ${ }^{1,4}$, Mauricio Tassoni Filho ${ }^{1}$, Anderson Ferreira ${ }^{2}$, Alexandre Leandro Pereira ${ }^{3}$, \\ Plínio Barbosa de Camargo ${ }^{1}$ \& Luiz Antonio Martinelli ${ }^{1}$ \\ ${ }^{1}$ Universidade de São Paulo, Centro de Energia Nuclear na Agricultura, Laboratório de Ecologia Isotópica, \\ Piracicaba, SP, Brazil. \\ ${ }^{2}$ Universidade Federal da Grande Dourados, Faculdade de Ciências Biológicas e Ambientais, Dourados, \\ MS, Brazil. \\ ${ }^{3}$ Universidade Federal do Paraná, Departamento de Biodiversidade, Laboratório de Ecologia, Pesca \\ e Ictiologia, Palotina, PR, Brazil. \\ ${ }^{4}$ Corresponding author: Fernanda Gaudio Augusto, e-mail: fernandagaudio@gmail.com
}

AUGuSto, F.G., TASSONI FIlHO, M., FERREIRA, A., PEREIRA, A.L., CAMARGO, P.B., MARTINELLI, L.A. Land use change in the Atlantic Forest affects carbon and nitrogen sources of streams as revealed by the isotopic composition of terrestrial invertebrates. Biota Neotropica. 15(2): e20140188. http://dx.doi.org/10.1590/1676-06032015018814

\begin{abstract}
Terrestrial invertebrates link terrestrial systems to aquatic ones, making vegetal material produced in the watershed available to aquatic food webs. In this study, using carbon and nitrogen stable isotopes, we evaluated the importance of introduced $\mathrm{C}_{4}$ grasses as a source of carbon in aquatic food webs of headwater streams of the coastal Atlantic Forest located on the north coast of the State of São Paulo, in the southeastern region of Brazil. Terrestrial invertebrates were collected in two streams: one where the main land cover was pristine montane Atlantic Forest (forest stream) and another where the main land cover was introduced $\mathrm{C}_{4}$ forage grasses for livestock (pasture stream). The average $\delta^{13} \mathrm{C}$ of terrestrial invertebrates collected in the forest stream $(-26.3 \pm 2.1 \%)$ was significantly $(\mathrm{p}<0.01)$ smaller than the average $\delta^{13} \mathrm{C}$ of terrestrial invertebrates collected in the pasture stream $\left(-15.7 \pm 4.7 \%\right.$ ), denoting a larger contribution of $\mathrm{C}_{4}$ grasses to terrestrial invertebrates of the pasture stream. The average $\delta^{15} \mathrm{~N}$ of terrestrial invertebrates of the forest stream $\left(4.1 \pm 2.4 \%\right.$ ) was significantly $(\mathrm{p}<0.01)$ lower than the average $\delta^{15} \mathrm{~N}$ of terrestrial invertebrates of the pasture stream $\left(9.5 \pm 2.7 \%\right.$ ). The relative contribution of $\mathrm{C}_{3}$ and $\mathrm{C}_{4}$ plants to terrestrial invertebrates was estimated using SIAR. In the forest stream, the $\mathrm{C}_{3}$ contribution was on average 0.75 ( 0.72 minimum to 0.79 maximum), and the $\mathrm{C}_{4}$ contribution was on average 0.25 ( 0.21 minimum to 0.28 maximum). In the pasture stream, the $\mathrm{C}_{3}$ contribution decreased to 0.20 ( 0.14 minimum to 0.26 maximum), and the $\mathrm{C}_{4}$ contribution increased to 0.80 ( 0.74 minimum to 0.86 maximum). These results have several implications for the ecosystem functioning as well as for recent changes in environmental policies of Brazil. The lower nutritional value of $\mathrm{C}_{4}$ grasses may not only decrease invertebrate performance, but also alter the stoichiometry of several components of the aquatic food webs with potential consequence for the whole ecosystem functioning. On the public policy side, recent changes in the Brazilian Forest Act, a series of laws that regulate land cover at the property level, reduced the width of the forested riparian area with potentially dangerous consequences for aquatic ecosystems.
\end{abstract}

Keywords: Atlantic Forest, land use, streams, stable isotopes, terrestrial invertebrate.

AUgusto, F.G., TASSONI FILHO, M., FERreirA, A., PEREIRA, A.L., CAMARGO, P.B., MARTINELLI, L.A. Mudanças no uso do solo na Mata Atlântica afetam fontes de carbono e nitrogênio em riachos como é revelado através da composição isotópica dos invertebrados terrestres. Biota Neotropica. 15(2): e20140188. http://dx.doi.org/10.1590/1676-06032015018814

Resumo: Os invertebrados terrestres constituem uma importante ligação entre os sistemas aquáticos e terrestres, disponibilizando o material vegetal produzido no entorno de riachos para as cadeias aquáticas. Nesse estudo, usando isótopos estáveis de carbono e nitrogênio, investigamos a introdução de plantas $\mathrm{C}_{4}$ como fonte de energia em cadeias alimentares aquáticas em riachos de cabeceira da Mata Atlântica, na costa norte do Estado de São Paulo, região sudeste do Brasil. Os invertebrados foram amostrados em dois riachos: um com cobertura de solo predominante de Floresta Atlântica Montana (riacho da floresta) e outro em que foram introduzidas gramíneas forrageiras para criação de gado (riacho da pastagem). A média dos valores de $\delta^{13} \mathrm{C}$ para os invertebrados terrestres coletados no riacho de floresta $(-26,3 \pm 2,1 \%$ o $)$ foi significativamente 
$(\mathrm{p}<0,01)$ menor que a média dos invertebrados coletados na pastagem $(-15,7 \pm 4,7 \%$ ), indicando uma maior contribuição de $\mathrm{C}_{4}$ para os invertebrados terrestres do riacho de pastagem. A média do $\delta^{15} \mathrm{~N}$ para os invertebrados do riacho da floresta $(4,1 \pm 2,4 \%$ ) foi significativamente $(\mathrm{p}<0,01)$ menor do que a média dos invertebrados na pastagem $\left(9,5 \pm 2,7 \%\right.$ ). A contribuição relativa de plantas $C_{3}$ e $C_{4}$ para os invertebrados terrestres foi estimada usando SIAR. No riacho de floresta, a contribuição de $\mathrm{C}_{3}$ foi em média 0,75 (mínimo de 0,72 e máximo de 0,79 ) e a contribuição de $\mathrm{C}_{4}$ foi em média 0,25 (mínimo de 0,21 e máximo de 0,28 ). No riacho de pastagem, a contribuição $C_{3}$ diminuiu para 0,20 (mínimo de 0,14 e máximo de 0,26 ) e a contribuição $C_{4}$ aumentou para 0,80 (mínimo de 0,74 e máximo de 0,86). Esses resultados têm várias implicações para 0 funcionamento dos ecossistemas, bem como para as mudanças recentes nas políticas ambientais do Brasil. $\mathrm{O}$ baixo valor nutricional de gramíneas $\mathrm{C}_{4}$ pode não só reduzir o desempenho de invertebrados, mas também alterar a estequiometria de vários componentes das cadeias alimentares aquáticas com potencial consequência para todo o funcionamento do ecossistema. Do lado da política pública, as recentes mudanças no Código Florestal brasileiro, uma série de leis que regulam a cobertura da terra no nível da propriedade, reduziu a largura da área de floresta ripária com consequências potencialmente perigosas para os ecossistemas aquáticos. Palavras-chave: Mata Atlântica, uso do solo, riachos, isótopos estáveis, invertebrados terrestres.

\section{Introduction}

The coastal Atlantic Forest of Brazil is concentrated mainly in the Serra do Mar, and runs parallel to the Brazilian coast for almost $1.000 \mathrm{~km}$ from Rio de Janeiro State in the north to Santa Catarina State in the south (Myers et al. 2000, Oyakawa et al. 2006). This biome is one of the richest in terms of number of plants and animals species, considered a hotspot of biodiversity (Myers et al. 2000).

Such richness of life did not prevent its displacement by croplands nor did it prevent unplanned urban sprawl (Monteiro \& Kaz 1991/92, Oyakawa et al. 2006, Ribeiro et al. 2009). Currently, only $12 \%$ of the 1.5 million $\mathrm{km}^{2}$ of the original Atlantic Forest remains intact (Ribeiro et al. 2009). Such changes in land use affect not only the structure and functioning of terrestrial ecosystems (Allan 2004), but also affects such characteristics of streams and rivers (Villela et al. 2002, Vanni 2002, Cross et al. 2005, Bukovinszky et al. 2008). There are several studies showing how land use changes affects the whole food web, from insects and benthonic macroinvertebrates (Ometto et al. 2000, Suriano et al. 2011, Colzani et al. 2013, Ligeiro et al. 2013) to fish species (Casatti et al. 2009, Alexandre et al. 2010).

Among lotic systems, the first order streams located in headwaters are the first link between the aquatic and terrestrial environments (Peterson et al. 2001). In these streams the food web encompasses a mixture of autochthonous and allochthonous sources (Pusey \& Arthington 2003). In such conditions, Riparian terrestrial ecosystem is an important source of organic matter (e.g. plant material, terrestrial invertebrates) for aquatic communities (Kawaguchi \& Nakano 2001, Pusey\& Arthington 2003, Barreto \& Aranha 2006, Casatti et al. 2009, Teresa \& Casatti 2013).

In watersheds, riparian areas assume a very important role as a source of food to lotics systems, especially in headwater streams (Naiman \& De' camps 1997, Ward 1998, Fisher et al. 1998, Helfield \& Naiman 2001, Pusey \& Arthington 2003, Casatti et al. 2012). Despite this importance, the displacement of riparian forests by monoculture and pasture for cattle is one of the main environmental problems in the Atlantic Forest biome (Silva et al. 2007). In Brazil, cultivated $\mathrm{C}_{4}$-grasses cover approximately 200 million ha (Lapola et al. 2013), and in São Paulo State more than $70 \%$ of riparian forests were replaced by $\mathrm{C}_{4}$-grasses (Silva et al. 2007).

Catford et al. (2013) suggested that climate change would facilitate the invasion of non-indigenous $\mathrm{C}_{4}$ plants in tropical areas. Dominance of $\mathrm{C}_{4}$ plants in future land use scenarios is especially important because it can have several ecological effects on tropical ecosystems (see Williams \& Baruch 2000 for a review). Particularly important to this study is the lower nutritional quality of $\mathrm{C}_{4}$ grasses compared with $\mathrm{C}_{3}$ plants due to the lower level of nutrients, higher fiber contents, and higher leaf toughness (Scheirs et al. 2001, Ehleringer et al. 2002, Clapcott \& Bunn 2003, Barbehenn et al. 2004). However, despite these nutritional limitations, it was shown that some insect species are well adapted to grass feeding (Barbehenn 2005). In aquatic food webs, it has been shown that the importance of $\mathrm{C}_{4}$ grasses seems to depend on the local conditions. For instance, $\mathrm{C}_{4}$ grass was an important component in small river food webs of the Piracicaba River Basin, located in the southeastern region of Brazil (Ferreira et al. 2012). On the other hand, it seems that $C_{4}$ grasses were less important as energy source in large tropical and sub-tropical watersheds of the Paraná River (Manetta et al. 2003, Hoeinghaus et al. 2007), and Amazon River (Araújo-Lima et al. 1986, Forsberg et al. 1993, Oliveira et al. 2006), nor were they important in sub-tropical and tropical watersheds of Australia (Clapcott \& Bunn 2003, Bunn et al. 2007).

Based on the discussion above, the main objective of this study was to evaluate the transport of exotic $\mathrm{C}_{4}$ forage grasses by terrestrial invertebrate to aquatic food webs of headwater streams of the coastal Atlantic Forest. In order to achieve this objective we collected terrestrial invertebrates from two watersheds; one where the dominant cover was Montane Atlantic Forest, and other where the dominant cover, especially in the riparian zone, was $\mathrm{C}_{4}$ forage grasses.

We analyzed the carbon and nitrogen stable isotopic composition of the terrestrial invertebrates to determine the contribution of $\mathrm{C}_{4}$ grasses to the aquatic food web. The carbon stable isotopic composition of $\mathrm{C}_{4}$ grasses is distinct from plants that follow the $\mathrm{C}_{3}$ photosynthetic pathway (Farquhar et al. 1989). This fact opens up the possibility of using carbon stable isotopic composition to track the fate of terrestrial $\mathrm{C}_{4}$ grasses in aquatic food webs (Bunn et al. 1997).

\section{Material and Methods}

\section{Study area}

Two headwater streams were selected for this study. The Ombrophyllus Dense Montane Forest (Velloso et al. 1991) dominates the watershed of the stream located in the branch 


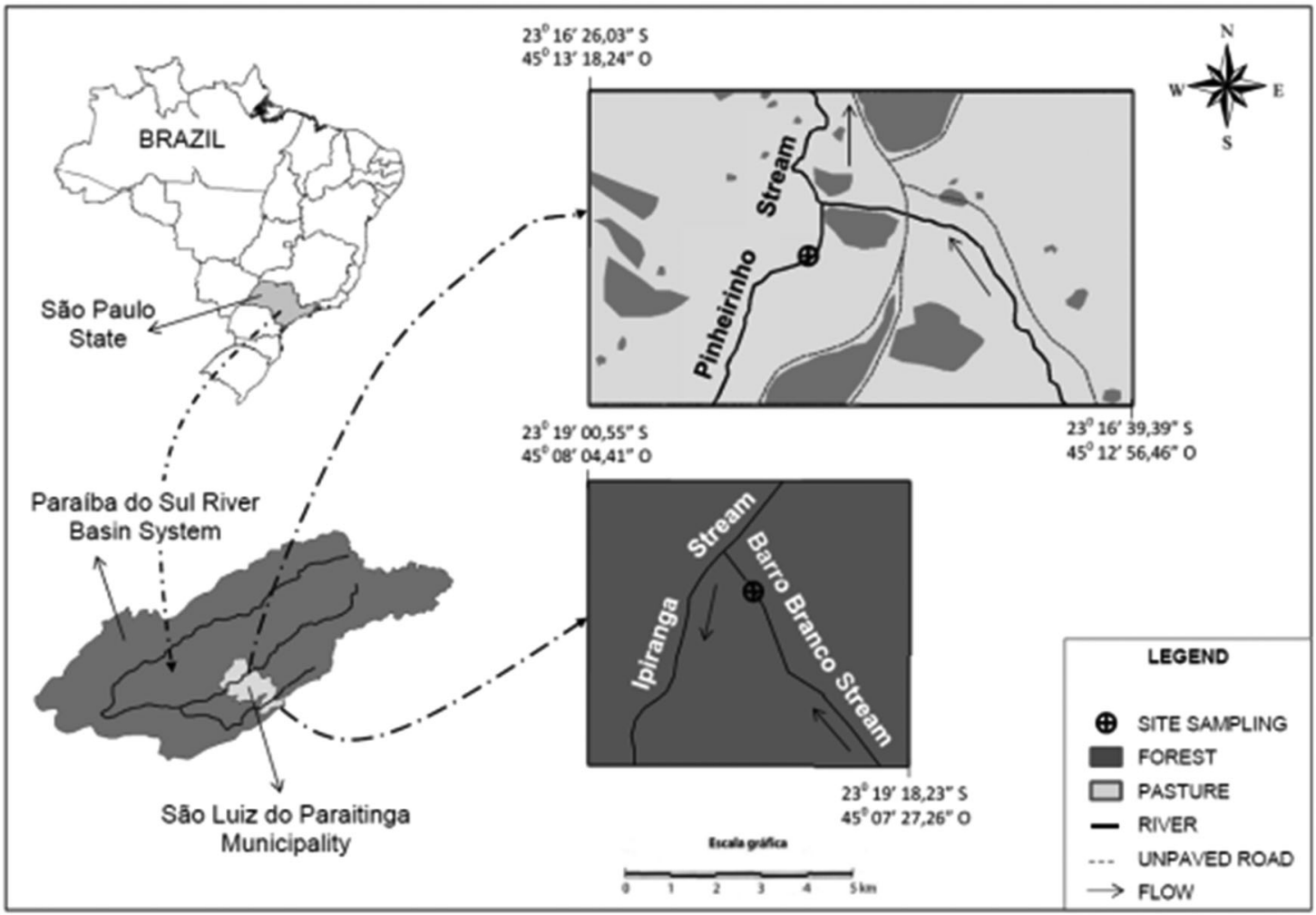

Figure 1. Study area showing the location of the pasture stream (Pinheirinho) and forest stream (Barro Branco).

Santa Virgínia of the State Park of Serra do Mar, hereafter referred to as "forested stream" (Figure 1). The other stream is dominated by pastures composed mainly of $\mathrm{C}_{4}$ grasses of the genus Brachiaria and is located approximately $30 \mathrm{~km}$ from the forested stream, hereafter referred to as "pasture stream" (Figure 1). The annual precipitation of the area is approximately $2.300 \mathrm{~mm}$ and the average annual temperature is $16^{\circ} \mathrm{C}$. This low average temperature for a sub-tropical area is due to the high elevation of the watersheds, approximately $1.000 \mathrm{~m}$ above sea level (Sousa Neto et al. 2008).

\section{Sampling}

Terrestrial invertebrates were collected in the beginning of the dry season (April of 2009) after the end of the heavy summer rains. Twenty-five floating plastic trays (pan traps) were randomly deployed on the water surface of the streams along a $150 \mathrm{~m}$ reach. The pan traps were filled with a mixture of water and 70\% alcohol. The sampled invertebrates were fixed in $70 \%$ alcohol and transported to the laboratory where they were identified according to order and morph types. After identification, samples were dried at $60^{\circ} \mathrm{C}$ for 48 hours and sent to analysis. Aquatic insect adults (Ephemeroptera and Trichoptera) were excluded from analyses of the pan trap samples, since our primary focus was on terrestrial invertebrates as allochthonous sources to the streams. Odonatas were included because according to Corbet (1962) the adults phases vary from a few days to months, therefore due to this extended living period it is possible that Odonatas contributes to river and streams trophic chains by transferring carbon from the terrestrial to aquatic systems.

We are aware that the use of alcohol to fix the invertebrates may alter their stable carbon isotopic composition
(Ruiz-Cooley et al. 2011, Syväranta et al. 2011, Xu et al. 2011). Additionally, it is difficult to make any correction in this alteration due to its variability; some studies show an increase in the stable carbon isotopic composition, while others show the opposite. However, in general these changes due to the alcohol use are minor, on the order of less than 1\%o (Ruiz-Cooley et al. 2011, Syväranta et al. 2011, Xu et al. 2011), and since in this study we are investigating the use of $\mathrm{C}_{4}$ and $\mathrm{C}_{3}$ plants by these animals that have great differences in their stable carbon isotopic composition (more than 10\%) we believe that any alteration due to the alcohol will not affect the main conclusions of this study.

\section{Isotopic analysis}

Dried samples were crushed to a fine powder and homogenized. Depending on the sample, 0.8 to $2.5 \mathrm{mg}$ of material was encapsulated, and carbon and nitrogen content as well their isotopic composition were determined by combustion an Elemental Analyzer (Carlo Erba, CHN-1100) coupled with a mass spectrometer Thermo Finningan Delta Plus at the Laboratory of Isotope Ecology of CENA-University of São Paulo. The analytical error obtained by the analysis of internal standards was $0.3 \%$ and $0.5 \%$ for carbon and nitrogen, respectively. Results were expressed in the classical delta $(\delta)$ per mil notation defined as:

$$
\delta=\left(\mathrm{R}_{\text {sample }} / \mathrm{R}_{\text {standard }}-1\right) \times 1000
$$

Where $\mathrm{R}_{\text {sample and }} \mathrm{R}_{\text {standard }}$ is the ratio of ${ }^{13} \mathrm{C}:{ }^{12} \mathrm{C}$ or ${ }^{15} \mathrm{~N}:{ }^{14} \mathrm{~N}$ of the sample and standard, respectively. The standard for carbon is the Vienna PDB and for nitrogen, the standard is the atmospheric air. 
Table 1. Mean and standard deviation (Stdev) of $\delta^{13} \mathrm{C}$ and $\delta^{15} \mathrm{~N}$ values of order of terrestrial invertebrates collected from floating trays on a forest stream. $\mathrm{N}$ denotes the number of samples, and Total denotes the overall mean and standard deviation.

\begin{tabular}{llllll}
\hline Order & $\mathbf{N}$. & $\begin{array}{l}\delta^{\mathbf{1 3}} \mathbf{C} \\
\text { Mean }\end{array}$ & Stdev & $\begin{array}{l}\delta^{\mathbf{1 5}} \mathbf{N} \\
\text { Mean }\end{array}$ & Stdev \\
\hline Aranae & 1 & -26.2 & & 4.4 & \\
Coleoptera & 4 & -25.3 & 1.7 & 3.8 & 1.5 \\
Collembola & 3 & -25.7 & 0.8 & 2.0 & 0.8 \\
Diptera & 44 & -26.5 & 2.4 & 4.7 & 2.3 \\
Hemiptera & 3 & -25.5 & 1.1 & 3.0 & 3.6 \\
Hymenoptera & 5 & -26.1 & 1.0 & 3.8 & 2.3 \\
Isopoda & 2 & -27.6 & 0.3 & 0.3 & 0.1 \\
Orthoptera & 2 & -24.6 & 1.1 & 0.8 & 1.0 \\
Total & 64 & -26.3 & 2.1 & 4.1 & 2.4 \\
\hline
\end{tabular}

\section{Sources contribution}

The relative contribution of $\mathrm{C}_{4}$ and $\mathrm{C}_{3}$ plants to terrestrial invertebrates was estimated using the computational package Stable Isotope Analysis in R (SIAR; Parnell et al. 2010). Terrestrial invertebrates were considered consumers, and $\mathrm{C}_{3}$ and $\mathrm{C}_{4}$ plants their food sources. In order to run SIAR, the carbon and nitrogen isotopic composition of the sources, and the isotopic fractionation values between diet-consumer have to be assigned. We assumed the average foliar $\delta^{13} \mathrm{C}$ $(-31.9 \pm 1.6 \%)$ and $\delta^{15} \mathrm{~N}(2.3 \pm 2.0 \%)$ values found among 184 tree specimens collected in the Montane Atlantic Forest a few kilometers from the forest stream (Martinelli LA, non published data). The average $\delta^{13} \mathrm{C}$ and $\delta^{15} \mathrm{~N}$ for the pasture watershed was assumed to be the average of $28 \mathrm{C}_{3}$ plant specimens collected along the pasture stream banks, which were equal to $-28.6 \pm 1.5 \%$ and $6.7 \pm 1.6 \%$, respectively (Pereira 2011). For $\mathrm{C}_{4}$ plants, the $\delta^{13} \mathrm{C}$ and $\delta^{15} \mathrm{~N}$ were assumed to be the average of six $\mathrm{C}_{4}$ plants specimens collected along the pasture stream banks, which were equal to $-11.9 \pm 0.2 \%$ and $7.8 \pm 1.5 \%$, respectively (Pereira 2011). Finally, the $\Delta^{13} \mathrm{C}$ and $\Delta^{15} \mathrm{~N}$ was assumed to be $+0.5 \pm 1.2 \%$ and $+2.3 \pm 1.6 \%$, according to McCutchan et al. (2003).

\section{Statistical analysis}

The $\delta^{13} \mathrm{C}$ values did not follow a normal distribution and could not be normalized by transformation. Therefore, the non-parametric Mann-Whitney test was used to compare $\delta^{13} \mathrm{C}$ and $\delta^{15} \mathrm{~N}$ values of invertebrates collected in the forest and pasture streams. The statistical tests were applied by using STATISTICA12 software and differences were accepted as significant at a $5 \%$ level of probability.

\section{Results}

The carbon and nitrogen isotopic compositions of 64 and 86 invertebrates were determined in the forest and pasture streams, respectively. Results of these analyses were grouped by order and are shown in Table 1 and 2 . The $\delta^{13} \mathrm{C}$ values of invertebrates in the forest stream varied from $-27.6 \pm 0.3 \%$ (Isopoda) to $-24.6 \% \pm \pm 1.1$ (Orthoptera), being the mean equal to $-26.3 \pm 2.1 \%$ o (Table 1 ). The $\delta^{13} \mathrm{C}$ values of invertebrates in the pasture stream varied from $-19.2 \pm 5.5 \%$ (Lepidoptera)
Table 2. Mean and standard deviation (Stdev) of $\delta^{13} \mathrm{C}$ and $\delta^{15} \mathrm{~N}$ values of order of terrestrial invertebrates collected from floating trays on pasture stream. $\mathrm{N}$ denotes the number of samples, and Total denotes the overall mean and standard deviation.

\begin{tabular}{llllll}
\hline Order & $\mathbf{N}$. & $\begin{array}{l}\delta^{\mathbf{1 3}} \mathbf{C} \\
\text { Mean }\end{array}$ & Stdev & $\begin{array}{l}\delta^{\mathbf{1 5}} \mathbf{N} \\
\text { Mean }\end{array}$ & Stdev \\
\hline Coleoptera & 5 & -16.3 & 3.2 & 11.0 & 2.4 \\
Collembola & 1 & -19.0 & & 7.1 & \\
Diptera & 32 & -18.9 & 4.3 & 9.4 & 2.7 \\
Hemiptera & 32 & -11.6 & 2.3 & 8.6 & 2.5 \\
Hymenoptera & 8 & -16.5 & 3.7 & 11.7 & 1.9 \\
Lepidoptera & 4 & -19.2 & 5.5 & 12.4 & 1.8 \\
Odonata & 2 & -16.0 & 1.3 & 7.0 & 0.4 \\
Orthoptera & 2 & -18.4 & 3.1 & 8.8 & 0.1 \\
Total & 94 & -15.7 & 4.7 & 9.5 & 2.7 \\
\hline
\end{tabular}

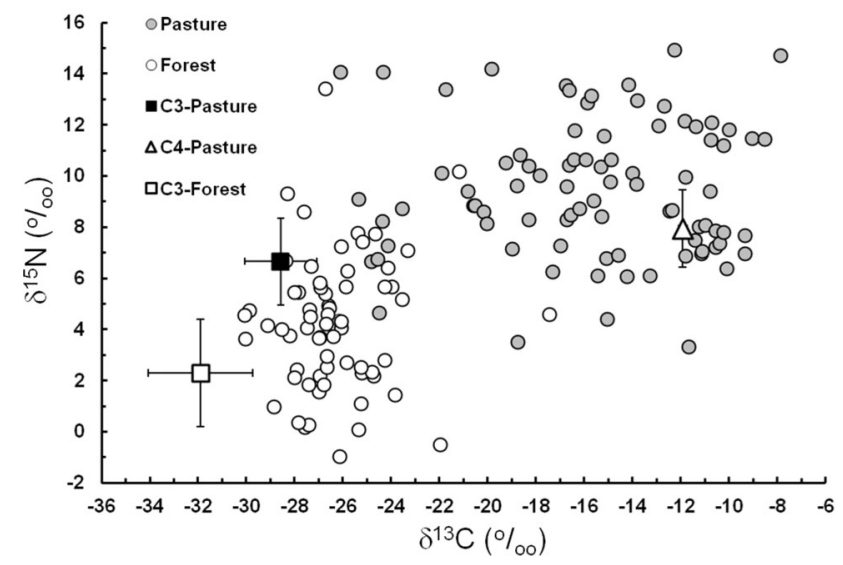

Figure 2. Carbon $\left(\delta^{13} \mathrm{C}\right)$ and nitrogen $\left(\delta^{15} \mathrm{~N}\right)$ stable isotope signatures of terrestrial invertebrates collected from floating trays placed in forested (empty circles) and pasture (filled circles) streams and mean isotopic values of $\mathrm{C}_{3}$ and $\mathrm{C}_{4}$ plants of pasture and $\mathrm{C}_{3}$ plants of forest. Bars are standard deviations.

to $-11.6 \pm 2.3 \%$ (Hemiptera), being the mean equal to $-15.7 \pm 4.7 \%$ o (Table 2 ), which was significantly higher than the mean value of invertebrates of the forest stream $(p<0.05)$

The $\delta^{15} \mathrm{~N}$ values of invertebrates in the forest stream varied from $0.3 \pm 0.1 \%$ (Isopoda) to $4.7 \pm 2.3 \%$ o (Lepidoptera), and the mean value was equal to $4.1 \pm 2.4 \%$ (Table 1 ). The $\delta^{15} \mathrm{~N}$ values of invertebrates of the pasture stream varied from $7.0 \pm 0.4 \%$ o (Odonata) to $12.4 \pm 1.8 \%$ o (Lepidoptera), and the mean value, equal to $9.5 \pm 2.7 \%$, was significantly higher $(\mathrm{p}<0.05)$ than the mean $\delta^{15} \mathrm{~N}$ of invertebrates in the forest stream (Table 2).

In the Figure 2, the $\delta^{13} \mathrm{C}$ values of invertebrates and plant sources are plotted versus the $\delta^{15} \mathrm{~N}$ values in the so-called $\delta$-space (Newsome et al. 2009). In general, the $\delta^{13} \mathrm{C}$ and $\delta^{15} \mathrm{~N}$ values of invertebrates of the forest stream were less variable than the pasture stream, and plotted near the $\mathrm{C}_{3}$ sources in the $\delta$-space (Figure 2). On the other hand, invertebrates of the pasture stream plotted between the $\mathrm{C}_{3}$ and $\mathrm{C}_{4}$ sources showed that both types of plant might be contributing to their diets.

The relative proportion of $\mathrm{C}_{3}$ and $\mathrm{C}_{4}$ sources to terrestrial invertebrates was estimated using SIAR (Parnell et al. 2010). As expected, in the forest stream, $\mathrm{C}_{3}$ plants predominate as the main food source of terrestrial invertebrates, the average 


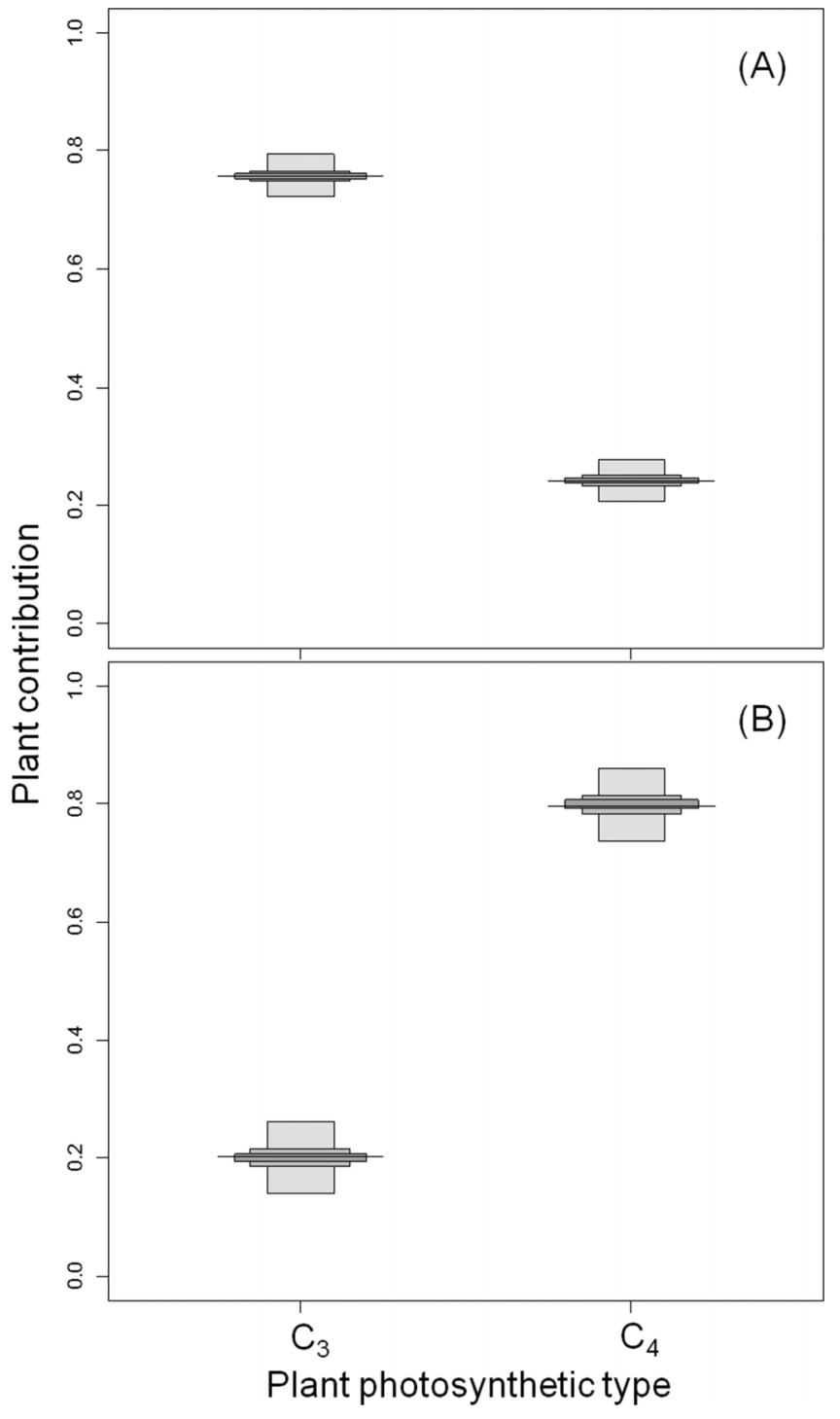

Figure 3. Relative contribution of $\mathrm{C}_{3}$ and $\mathrm{C}_{4}$ plants to terrestrial invertebrates in (A) forest stream and (B) pasture stream estimated by the stable isotope analysis in R (SIAR; Parnell et al. 2010) mixing model at $1 \% 25 \%, 50 \%$ and $99 \%$ probability levels.

contribution was 0.75 , the minimum 0.72 and the maximum 0.79 (Figure 3 ). There was also some unexpected $\mathrm{C}_{4}$ contribution to the forest stream terrestrial invertebrates.

The average $\mathrm{C}_{4}$ contribution in the forest stream was 0.25 , the minimum 0.21 and the maximum 0.28 (Figure 3). In the pasture stream, most of carbon assimilated by the terrestrial invertebrates had a $\mathrm{C}_{4}$ origin. The average contribution of these plants was 0.80 , the minimum 0.74 and the maximum 0.86 . The average contribution of $\mathrm{C}_{3}$ was 0.20 , the minimum 0.14 and the maximum 0.26 (Figure 3 ).

\section{Discussion}

Caswell et al. (1973) hypothesized that $\mathrm{C}_{4}$ plants are avoided by herbivores, especially insects, due to their lower nutritional content compared to $\mathrm{C}_{3}$ plants. More recently, Barbehenn (2005) showed that leaf-chewing grass-feeding insects such as the grasshopper Camnula pellucid and
Melanoplus sanguinipes are capable of crushing and extracting nutrients from the bundle sheath cells of $\mathrm{C}_{4}$ grasses, suggesting that these insects may take advantage of the presence of $\mathrm{C}_{4}$ grasses in the landscape.

We found in this study that the conversion of forest to pasture lands in the coastal Atlantic Forest of Southeastern Brazil influenced the diet composition of terrestrial invertebrates collected on stream surfaces. The contribution of terrestrial $\mathrm{C}_{4}$ plants to these invertebrates was significantly higher in the pasture than in the forest stream (Figure 3). According to our estimates an average of approximately $78 \%$ of the carbon of these invertebrates had a $\mathrm{C}_{4}$ origin (Figure 3 ).

It is important to mention that such an estimate has a degree of uncertainty associated with several factors. First, due to logistical constraints our samples of invertebrates were fixed in alcohol, which may especially alter $\delta^{13} \mathrm{C}$ values, although this difference seems to be minor, generally between $0.8 \%$ o and 2.5\%o (Ruiz-Cooley et al. 2011, Syväranta et al. 2011, $\mathrm{Xu}$ et al. 2011). Regarding this change, it is important to emphasize that in this study, we are evaluating differences in contribution of $\mathrm{C}_{3}$ and $\mathrm{C}_{4}$ plants that have a significant differences in their $\delta^{13} \mathrm{C}$ value, approximately $17 \%$ and $19 \%$ for pasture and forest plants, respectively. Therefore, minor changes in the isotopic composition due to alcohol probably had a minor effect on our results.

Second, we consider constant values for the isotopic fractionation between diet-consumer $\left(\Delta^{13} \mathrm{C}=+0.5 \%\right.$ and $\Delta{ }^{15} \mathrm{C}=+2.3 \%$ ) according to McCutchan et al. (2003). There are several studies showing that the $\Delta^{13} \mathrm{C}$ and $\Delta^{15} \mathrm{C}$ may vary due to consumer, and diet characteristics and composition (McCutchan et al. 2003, Codron et al. 2011). As we previously mentioned, the composition and nutritional value of $\mathrm{C}_{3}$ and $\mathrm{C}_{4}$ grasses are different (Ehleringer et al. 2002, Barbehenn 2005); this may lead to differences in the $\Delta^{13} \mathrm{C}$ and the $\Delta{ }^{15} \mathrm{C}$ values for $\mathrm{C}_{3}$ and $\mathrm{C}_{4}$ plants; and in this study we assumed the same isotopic fractionation for both types of plants.

In the Neotropics the contribution of $\mathrm{C}_{4}$ plants to terrestrial invertebrates appears to be a common in large rivers as well as streams. For instance, Adis \& Victoria (2001) showed that species of Tucayaca gracilis (Orthoptera), Stenacris $f$. fissicauda (Orthoptera), and Mestosoma hylaeicurn (Polydesmida) living in the Marchantaria Island, in the Solimões River floodplains had $\delta^{13} \mathrm{C}$ values ranging from approximately $-14 \%$ to $-11 \%$, showing the importance of $\mathrm{C}_{4}$ grasses Paspalum repens and Echinochloa polystachya, two naturally occurring grasses in the region. Oliveira et al. (2006) working on Camaleão Lake in the same island found that $\delta^{13} \mathrm{C}$ values of terrestrial insects collected on $\mathrm{C}_{4}$ vegetation varied from approximately $-13 \%$ to $-17 \%$, confirming the importance of these plants to the local fauna of insects. Finally, Ferreira et al. (2012), studying watersheds of southeastern Brazil where the original forest was replaced by $\mathrm{C}_{4}$ forage grasses, also found that that these plants were the most important components of the terrestrial invertebrate diets.

If the $\mathrm{C}_{4}$ material carried by terrestrial insects enters in aquatic food webs appears to be a function of watershed physical characteristics and the food habits of fish species. For instance, in large watersheds, like those in the Solimões and upper Amazon rivers, Forsberg et al. (1993) found that for most fish species, the contribution of $\mathrm{C}_{4}$ carbon was low. However, for some species (Pterygoplichthys diatus, Hydrolycus scomberoides, Heros sp., Hypostomus plecostomus and Schizodon 
fasciatus), the $\mathrm{C}_{4}$ contribution was at least $40 \%$. Likewise, Manetta et al. (2003) found that most fish species had a low contribution of $\mathrm{C}_{4}$ carbon in lagoons of the Upper Paraná River floodplains; however, two fish species (Schizodon borellii, and Leporinus lacustris) had a significant contribution from $\mathrm{C}_{4}$ plants. Also in the Upper Paraná River Basin, Hoeinghaus et al. (2007) showed that only in high-gradient rivers $\left(1.3 \mathrm{~m} . \mathrm{km}^{-1}\right), \mathrm{C}_{4}$ carbon made a significant contribution, especially to the species Schizodon nasutus. On the other hand, in a small watershed $\left(0.1\right.$ to $\left.1 \mathrm{~km}^{2}\right)$ of southeastern Brazil where the original vegetation was displaced mainly by pastures, the contribution of $\mathrm{C}_{4}$ carbon for the fish species Astyanax paranae and Bryconamericus iheringii was higher $(60 \%)$ than in large tropical watersheds (Ferreira et al. 2012).

An unexpected result was the average contribution of 0.23 (up to 0.27 ) of $\mathrm{C}_{4}$ plants to the terrestrial invertebrates of the forest stream. This fact was unexpected because we did not see any $\mathrm{C}_{4}$ plants along the forest stream banks near the sampling site. Therefore, there are two possibilities to explain the $\mathrm{C}_{4}$ signal in the terrestrial invertebrates of the forest stream: one is that there are $\mathrm{C}_{4}$ plants along the forest stream banks that were not observed in our visual inspection or they were located in a distant stream in relation to the sampling site; or a second possibility is that terrestrial invertebrates are feeding on $\mathrm{C}_{4}$ grasses located on the side of a back road located in the vicinity of our sampling site.

The $\delta^{15} \mathrm{~N}$ values of terrestrial invertebrates were also significantly higher in the pasture streams compared to forest streams (Figure 2). The main cause of such differences may be due to the higher $\delta^{15} \mathrm{~N}$ values observed in plants of the pasture stream watershed. However, it is also possible that the trophic position between terrestrial invertebrates of forest and pasture streams are different, since it is well established that $\delta^{15} \mathrm{~N}$ values increase toward higher trophic levels due to a preferential loss of ${ }^{14} \mathrm{~N}$ along the food chain (Post et al. 2000, McCutchan et al. 2003, Martínez del Rio et al. 2009). As we had classified terrestrial invertebrates only to the order level, it is difficult to determine a trophic isotopic fractionation for invertebrates captured in the forest and pasture-streams. Therefore, we cannot provide a more precise cause for the higher $\delta^{15} \mathrm{~N}$ values observed in invertebrates of the pasture stream.

It is also worth speculating about the ecological implications caused by the entrance of $\mathrm{C}_{4}$ carbon in aquatic food webs. There are two main aspects to be considered, one is the consequence for terrestrial invertebrates and the other is the consequence for the ecosystem functioning itself. Regarding the first aspect, the plant quality (elemental composition and defense substances) affects the performance of herbivorous insects, including fecundity (Awmack \& Leather 2002). Barbehenn et al. (2004) showed that the growth rate of grasshoppers (Melanoplus sanguinipes) was approximately $70 \%$ higher in $\mathrm{C}_{3}$-feeding than in $\mathrm{C}_{4}$-feeding animals. Therefore, it is reasonable to hypothesize that the performance of terrestrial invertebrates may be different in pasture-dominated compared to forest-dominated watersheds. Such differences in performance may be effective not only at the individual but also at population level (Awmack \& Leather 2002). Secondly, despite the apparent poor invertebrate performance in $\mathrm{C}_{4}$-dominated landscapes, it is also important to consider that nutrient ratios (C:N, C:P or $\mathrm{N}: \mathrm{P}$ ) of consumers may change in accordance with the substrate quality, and such changes may affect the whole food chain and ecosystem functioning (Cross et al. 2005, Bukovinszky et al. 2008), since animals, including invertebrates, may greatly affect nutrient dynamics in freshwater systems (Vanni 2002).

Finally, our findings also have important policy implications. The Brazilian Forest Act that regulates land cover at the rural property level was recently changed by the Brazilian Congress. Although there are still pending issues on the final bill, there will be probably a reduction of the extent of the riparian area that has to remain forested. The $30 \mathrm{~m}$ forested buffer zone established in a longstanding version of the Forest Act will probably be significantly reduced. As we saw in this study, the lack of riparian forest and the implementation of feeding $\mathrm{C}_{4}$ grasslands to livestock (the largest land use in Brazil) will change the quality of the vegetal material transferred from the terrestrial to aquatic systems by terrestrial invertebrates. As previously mentioned, this change in the substrate quality has the potential to alter not only the performance of terrestrial invertebrates as well as modify the entire food web with consequences for the ecosystem functioning. The maintenance of a 30m-riparian buffer zone would definitely help minimize the effect of upland cropped areas on streams (Ferreira et al. 2012).

There was a major shift from $\mathrm{C}_{3}$-dominated to $\mathrm{C}_{4}$-dominated plants in the diet of terrestrial invertebrates of pristine forest to disturbed pasture streams. These major changes in food web fuels may affect not only the performance of terrestrial invertebrates but also may lead to important alterations of the aquatic ecosystem functioning of pasture streams compared to forest streams. These changes may be exacerbated by recent changes in the Brazilian Forest Act, namely a decrease of the riparian buffer zone, one of the most important changes due to its ecological implications.

\section{Acknowledgements}

FAPESP (Fundação de Amparo à Pesquisa do Estado de São Paulo) for first author fellowship, José Gilberto de Moraes for use of Laboratory of Acarology Agricultural (Esalq / USP), Alessandra Svonka Palmeiro for the maps and Jim Hesson for their help in reviewing language.

\section{References}

ADIS, J. \& VICTORIA, R.L. 2001. $\mathrm{C}_{3}$ or $\mathrm{C}_{4}$ macrophytes: a specific carbon source for the development of semi-aquatic and terrestrial arthropods in Central Amazonian river-floodplains to $\delta^{13}$ values. Isot. Environ. Healt. S. 37(3):193-198.

ALEXANDRE, C.V., ESTEVES, K.E. \& DE MOURA, E. \& MELLO, M.M.A.M. 2010. Analysis of fish communities along a rural-urban gradient in a neotropical stream (Piracicaba River Basin, São Paulo, Brazil). Hydrobiologia 641:97-114. http://dx.doi.org/10.1007/s10750009-0060-y

ALLAN, J.D. 2004. Landscapes and Riverscapes: The Influence of Land Use on Stream Ecosystems. Annu. Rev. Ecol. Evol. S. 35:257-284. http://dx.doi.org/10.1146/annurev.ecolsys.35.120202.110122

ARAÚJO-LIMA, C.A.R.M., FORSBERG, B.R., VICTORIA, R. \& MARTINELLI, L.A. 1986. Energy sources for detritivorous fishes in the Amazon. Science 234:1256-1258.

AWMACK, C.S., LEATHER, S.R. 2002. Host plant quality and fecundity in herbivorous insects. Annu. Rev. Entomol. 47:817-44.

BARBEHENN, R.V., KAROWE, D.N. \& CHEN, Z. 2004. Performance of a generalist grasshopper on a $\mathrm{C}_{3}$ and a $\mathrm{C}_{4}$ grass: compensation for the effects of elevated $\mathrm{CO}_{2}$ on plant nutritional quality. Oecologia 140:96-103. 
BARBEHENN, R.V. 2005. Grasshoppers efficiently process the bundle sheath cells in a $\mathrm{C}_{4}$ grass: implications for patterns of host plant utilization. Entomol. Exp. Appl. 116:209-217.

BARRETO, A.P. \& ARANHA, J.M.R. 2006. Alimentação de quatro espécies de Characiformes de um riacho de Floresta Atlântica, Guaraqueçaba, Paraná, Brasil. Rev. Bras. Zool. 23:779-788.

BUKOVINSZKY, T., VEEN, F.J.F., JONGEMA, Y. \& DICKE, M. 2008. Direct and indirect effects of resource quality on food web structure. Science 319(5864):804-807.

BUNN, S.E., DAVIES, P.M. \& KELlAWAY, D.M. 1997. Contributions of sugar cane and invasive pasture grass to the aquatic food web of a tropical lowland stream. Mar. Freshwater. Res. 48:173-179.

BUNN, S.E., ABAL, E.G., GREENFIELD, P.F. \& TARTE, D. M. 2007. Making the connection between healthy waterways and healthy catchments: South East Queensland, Australia. Water Sci. Technol.: Water Supply 7:93-100.

CASATTI, L., VERONEZI JÚNIOR, J.L. \& FERREIRA, C.P. 2009. Diet of the armored catfish Aspidoras fuscoguttatus (Ostariophysi, Callichthyidae) in streams with different limnological and structural features. Biota Neotrop. 9(1):113-121. http://www.biotaneotropica.org.br/v9n1/en/abstract?article + bn02109012009 (last acess 01/11/2013).

CASATTI, L., TERESA, F.B., GONÇALVES-SOUZA, T., BESSA, E., MANZOTTI, A.R., GONÇALVES, C.S. \& ZENI, J.O. 2012. From forests to cattail: how does the riparian zone influence stream fish? Neotrop. Ichthyol. 10(1):205-214.

CASWELL, H., REED, F., STEPHENSON, S.N. \& WERNER, P.A 1973. Photosynthetic pathways and selective herbivory: a hypothesis. Am. Nat. 107:465-480.

CATFORD, J.A., NAIMAN, R.J., CHAMBERS, L.E., ROBERTS, J., DOUGLAS, M. \& DAVIES, P. 2013. Predicting novel riparian ecosystems in a changing climate. Ecosystems 16:382-400.

CLAPCOTT, J.E. \& BUNN, S.E. 2003. Can $\mathrm{C}_{4}$ plants contribute to aquatic food webs of subtropical streams? Freshwater Biol. 48:1105-1116

CODRON, D., CODRON, J., SPONHEIMER, M., BERNASCONI, S.M. \& CLAUSS, M. 2011. When animals are not quite what they eat: diet digestibility influences 13C-incorporation rates and apparent discrimination in a mixed-feeding herbivore. Can. J. Zoolog. 89:453-465.

COLZANI, E. \& ALVES, M.A.M. 2013. Richness and distribution of unicellular eukaryotes in three streams under anthropic influence, Ivinhema City, Mato Grosso do Sul State, Brazil. Revista Ambiente \& Água 8(2):192-203.

CORBET, P.S. 1992. A biology of dragonflies. London, Witherby. $247 \mathrm{p}$.

CROSS, W.F., BENSTEAD, J.P., FROST, P.C. \& THOMAS S.A. 2005. Ecological stoichiometry in freshwater benthic systems: recent progress and perspectives. Freshwater Biol. 50:1895-1912. http://dx.doi.org/10.1111/j.1365-2427.2005.01458.x

EHLERINGER, J.R., BOWLING, D.R., FLANAGAN, L.B., FESSENDER, J., HELLIKER, B., MARTINELLI, L.A. \& OMETTO, J.P.H. 2002. Stable isotopes and carbon cycle process in forests and grasslands. Plant Biol. 4:181-189.

FARQUHAR, G.D., EHLERINGER, J.R. \& RUBICK, K. 1989. Discrimination and photosynthesis. Annu. Rev. Plant. Phys. 40:503-537.

FERREIRA, A., DE PAULA, F.R., FERRAZ, S.F.B., GERHARD, P., KASHIWAQUI, E.A.L., CYRINO, J.E.P. \& MARTINELLI, L.A. 2012. Riparian coverage affects diets of characids in neotropical streams. Ecol. Freshw. Fish 21:12-22. http://dx.doi.org/ 10.1111/j.1600-0633.2011.00518.x

FISHER, S.G., GRIMM, N.B., MART, E, HOLMES, R.M. \& JONES JR., J.B. 1998. Material spiraling in stream corridors: a telescoping ecosystem model. Ecosystems 1:19-34.

FORSBERG, B.R., ARAUJO-LIMA, C.A.R.M., MATINELLI, L.A., VICTORIA, R.L. \& BONASSI, J.A. 1993. Autotrophic carbon sources for fish of the central amazon. Ecology 74:643-652.
HELFIELD, J.M. \& NAIMAN, R.J.. 2001. Effects of salmon-derived nitrogen on riparian forest growth and implications for stream productivity. Ecology 82:2403-2409.

HOEINGHAUS, D.J., WINEMILLER, K.O. \& BIRNBAUM, J.S. 2007. Local and regional determinants of stream fish assemblage structure: inferences based on taxonomic vs. functional groups. J. Biogeogr. 34:324-338.

KAWAGUCHI, Y. \& NAKANO, S. 2001. Contribution of terrestrial invertebrates to the annual resource budget for salmonids in forest and grassland reaches of a headwater stream. Freshwater Biol. 46:303-316

LAPOLA, D.M., MARTINELLI, L.A., PERES, C.A., OMETTO, J.P. H.B., FERREIRA, M.E., NOBRE, C.A., AGUIAR, A.P.D., BUSTAMANTE, M.M.C., CARDOSO, M.F., COSTA, M.H., JOLY, C.A., LEITE, C.C., MOUTINHO, P., SAMPAIO, G., STRASSBURG, B.B.N. \& VIEIRA, I.C.G. 2013. Pervasive transition of the Brazilian land-use system. Nat. Clim. Chang. 4: 27-35. http://dx.doi.org/10.1038/nclimate2056.

LIGEIRO, R., FERREIRA, W., HUGHES, R.M. \& CALLISTO, M. 2013. The problem of using fixed-area subsampling methods to estimate macroinvertebrate richness: a case study with Neotropical stream data. Environ. Monit. Assess. 185:4077-4085.

MANETTA, G.L., BENEDITO-CECILIO, E. \& MARTINELLI, L. A. 2003.Carbon sources and trophic position of the main species of fishes of Baía River, Paraná River Floodplain, Brazil. Braz. J. Biol. 63:283-290.

MARTÍNEZ DEL RIO C., SABAT, P., ANDERSON-SPRECHER, R. \& GONZALEZ, S.P. 2009. Dietary and isotopic specialization: the isotopic niche of three Cinclodes ovenbirds. Oecologia 161: 149-159.

MCCUTCHAN, J.H., LEWIS, W.M., KENDALL, C. \& MCGRATH, C.C. 2003. Variation in trophic shift for stable isotope ratios of carbon, nitrogen, and sulfur. Oikos 102, 378-390.

MONTEIRO, S. \& KAZ, L. 1991-92. Floresta Atlântica. Edições Alumbramento/Livroarte Editora, Rio de Janeiro.

MYERS, N., MITTERMEIER, R.A., MITTERMEIER, C.G., FONSECA, G.A.B. \& KENT, J. 2000. Biodiversity hotspots for conservation priorities. Nature 403:852-858.

NAIMAN, R.J. \& DE' CAMPS, H. 1997. The ecology of interfaces: riparian zones. Annu. Rev. Ecol. Syst. 28:621-665.

NEWSOME, S.D., TINKER, M.T., MONSON, D.H., OFTEDAL, O.T., RALLS, K., STAEDLER, M.M., FOGEL, M.L. \& ESTES, J.A. 2009. Using stable isotopes to investigate individual diet specialization in California sea otters (Enhydra lutris nereis). Ecology 90:961-974.

OLIVEIRA, A.C.B., MARTINELLI, L.A., MOREIRA, M.Z., SOARES, M.G.M. \& CYRINO, J.E.P. 2006. Seasonality of energy sources of Colossoma macropomum in a floodplain lake in the Amazon - lake Camaleão, Amazonas, Brazil. Fisheries Manag. Ecol. 13:135-142.

OMETTO, J.P.H.B., MARTINELLI, L.A., BALLESTER, M.V.R., GESSNER, A., KRUSCHE, A., VICTORIA, R.L. \& WILLIANS, M. 2000. Effects of land use on water chemistry and macroinvertebrates in two streams of Piracicaba river basin, southeast Brazil. Freshwater Biol. 44:327-337.

OYAKAWA, O.T., AKAMA, A., MAUTARI, K.C. \& NOLASCO, J. C. 2006. Peixes de riachos da Mata Atlântica nas Unidades de Conservação do Vale do Rio Ribeira de Iguape no Estado de São Paulo. Editora Neotropica, São Paulo.

PARNELL, A.C., INGER, R., BEARHOP, S. \& JACKSON, A.L. 2010. Source partitioning using stable isotopes: coping with too much variation. PLoS ONE 5(3):e9672.

PEREIRA, A.L.. 2011. Fontes de carbono e nitrogênio para consumidores aquáticos nas microbacias da Mata Atlântica utilizando-se isótopos estáveis. Tese de Doutorado, Universidade de São Paulo, Piracicaba.

PETERSON, B.J et al. 2001. Control of nitrogen export from watersheds by headwater streams. Science 292:86-90. http://dx.doi.org/10.1126/ science. 1056874 
POST, D.M., PACE, M.L. \& HAIRSTON, N.G. 2000. Ecosystem size determines food-chain length in lakes. Nature 405(6790): 1047-1049.

PUSEY, B.J. \& ARTHINGTON, A.H. 2003. Importance of the riparian zone to the conservation and management of freshwater fish: a review. Mar.Freshwater Res. 54:1-16.

RIBEIRO, M.C., METZGER, J.P., MARTENSEN, A.C., PONZONI, F.J. \& HIROTA, M.M. 2009. Brazilian Atlantic forest: how much is left and how is the remaining forest distributed? Implications for conservation. Biol. Conserv. 142:1141-1153.

RUIZ-COOLEY, R.I., GARCIA, K.Y. \& HETHERINGTON, E.D. 2011. Effects of lipid removal and preservatives on carbon and nitrogen stable isotope ratios of squid tissues: Implications for ecological studies. J. Exp. Mar. Biol. Ecol. 407: 101-107. http:// dx.doi.org/10.1016/j.jembe.2011.07.002SCHEIRS.

SCHEIRS, J., DEBRUYN, L.D.E. \& VERHAGEN, R. 2001. A test of the $\mathrm{C} 3-\mathrm{C} 4$ hypothesis with two grass miners. Ecology 82:410-421.

Silva, A.M., CASATTI, L., ÁlVARES, C.A., LEITE, A.M., MARTINELLI, L.A. \& DURRANT, S.F. 2007. Soil loss and habitat quality in streams of a meso-scale river basin. Sci. Agric. 64:336-343.

SOUSA NETO, E., CARMO, J.B., KELLER, M., MARTINS, S.C., ALVES, L.F., VIEIRA, S.A., PICCOLO, M.C., CAMARGO, P., COUTO, H.T.Z. \& JOLY, C.A. 2011. Soil-atmosphere exchange of nitrous oxide, methane and carbon dioxide in a gradient of elevation in the coastal Brazilian Atlantic Forest. Biogeosciences 8:733-742.

SURIANO, M.T., FONSECA-GESSNER, A.A., ROQUE, F.O. \& FROEHLICH, C.G. 2011. Choice of macroinvertebrate metrics to evaluate stream conditions in Atlantic Forest, Brazil. Environ. Monit. Assess. 175:87-101.

SYVÄRANTA, J., MARTINO, A., KOPP, D., CÉRÉGHINO, R. \& SANTOUL, F. 2011. Freezing and chemical preservatives alter the stable isotope values of carbon and nitrogen of the Asiatic clam (Corbicula fluminea). Hydrobiologia 658:383-388.

TERESA, F.B. \& CASATTI, L. 2013. Development of habitat suitability criteria for Neotropical stream fishes and an assessment of their transferability to streams with different conservation status. Neotrop. Ichthyol. 11(2):395-402. http://dx.doi.org/10.1590/S167962252013005000009 .

VANNI, M.J. 2002. Nutrient cycling by animals in freshwater ecosystems. Annu. Rev. Ecol. Syst. 33:341-370.

VELOSO, H.P., RANGEL FILHO, A.L.R. \& LIMA, J.C.A. 1991. Classificação da vegetação brasileira, adaptada a um sistema universal. Brasília: IBGE, Departamento de Recursos Naturais e Estudos Ambientais.

VILLELA, F.S., BECKER, F.G. \& HARTZ, S.M. 2002. Diet of Astyanax species (Teleostei, Characidae) in an Atlantic forest river in southern Brazil. Braz. Arch. Biol. Techn. 45:223-232.

WARD, J.V., BRETSCHKO, G., BRUNKE, M., DANIELOPOL, D., GIBERT, J., GONSER, T. \& HILDREW, A.G. 1998. The boundaries of river systems: the metazoan perspective. Freshwater Biol. 40:531-569.

WILLIAMS, D.G. \& BARUCH, Z. 2000. African grass invasion in the Americas: Ecosystem consequences and the role of ecophysiology. Biol. Invasions 2:123-140.

XU, J., YANG, Q., ZHANG, M., XIE, P. \& HANSSON, L-A. 2011. Preservation effects on stable isotope ratios and consequences for the reconstruction of energetic pathways. Aquat. Ecol. 45:483-492.

Received 11/12/2014 Accepted 1/12/2015 